\title{
Identification of Disease Risk DNA Variations is Shaping the Future of Precision Health
}

\author{
Walid D. Fakhouri ${ }^{1,2, *(1)}$ and Ariadne Letra ${ }^{1,2}$ (]) \\ 1 Center for Craniofacial Research, Department of Diagnostic and Biomedical Sciences, School of Dentistry, \\ University of Texas Health Science Center at Houston, Houston, TX 77054, USA; \\ Ariadne.M.Letra@uth.tmc.edu \\ 2 Pediatric Research Center, McGovern Medical School, University of Texas Health Science Center, Houston, \\ TX 77030, USA \\ * Correspondence: Walid.D.Fakhouri@uth.tmc.edu
}

Received: 4 June 2019; Accepted: 11 June 2019; Published: 13 June 2019

\begin{abstract}
In recent years, the knowledge generated by decoding the human genome has allowed groundbreaking genetic research to better understand genomic architecture and heritability in healthy and disease states. The vast amount of data generated over time and yet to be generated provides the basis for translational research towards the development of preventive and therapeutic strategies for many conditions. In this special issue, we highlight the discoveries of disease-associated and protective DNA variations in common human diseases and developmental disorders.
\end{abstract}

Keywords: genomic evolution; coding DNA variations; noncoding DNA variations; alternative transcriptional start site; alternative splicing and mRNA stability; post-transcriptional and -translational regulation

Sequencing of the whole genome of many organisms has provided the scientific community with a tremendous amount of information to determine which part of the mammalian genome is under constraint or undergoing rapid turnover. Based on DNA conservation, evolutionary studies have shown that DNA changes are taking place at a higher rate in noncoding regulatory regions and at a much lower rate within gene coding sequences [1]. Each human cell has about 22,000 genes that are distinctly regulated over time and location to determine the fate of each cell. The code for regulating these thousands of genes is encrypted, particularly in noncoding DNA sequences and the associated epigenome modifications [1]. DNA variations in regulatory elements can disrupt gene expression and alter epigenome modifications, whereas coding mutations can alter protein function, stability, or localization [2,3]. Notably, molecular and genetic studies using animal models have shown that DNA variations play a critical role in increasing fitness to environmental conditions [4]. In contrast, certain DNA variations increase the risk for Mendelian and complex diseases [5-8].

To emphasize the importance of gene regulation, genome-wide association studies (GWAS) of human common diseases demonstrate that $10 \%$ of the disease-related single nucleotide polymorphisms (SNPs) are located in amino acid coding sequences, whereas around $90 \%$ of the disease-associated SNPs fall outside of protein coding regions [2,3,9]. Identification of pathological DNA variants is critical for early diagnosis and better prognosis of genetic diseases in high-risk individuals and also for developing targeted therapies in patients with existing genetic disorders $[9,10]$. Research has been previously directed towards DNA variations located within coding sequences because of their direct effect on the function of the corresponding gene/protein product. Based on evolutionary studies as well as omics and GWAS data, understanding the underlying mechanism by which noncoding DNA variations alter gene function and identification of differentially expressed genes is critical for identifying genetic factors that increase the risk for common complex diseases [10]. Furthermore, 
developing computational modeling for predicting the impact of genetic and epigenetic factors on disease prognosis and severity will pave the way for the implementation of precision health strategies focusing on prevention and targeted therapy rather than a 'one pill fits all' approach [8,9].

This Special Issue on DNA Variations in Evolution and Human Diseases features a series of studies that identify new pathological and protective DNA variations in common human diseases and conditions including chronic periodontitis [11], familial adenomatous polyposis [12], asthma [13], rheumatoid arthritis [14], multiple myeloma [15], dental implant failure [16], tooth agenesis [17], tuberculosis [18], and developmental disorders [19,20].

Author Contributions: Original draft preparation, W.D.F.; Review and editing, A.L.; Funding acquisition, W.D.F., A.L.

Funding: The authors are grateful for the financial support from NIH/NIGMS grant R15GM122030-01 to WDF and NIH/NIDCR R03-DE024596 to A.L.

Conflicts of Interest: The authors declare no conflicts of interest.

\section{References}

1. $\quad$ Lindblad-Toh, K.; Garber, M.; Zuk, O.; Lin, M.F.; Parker, B.J; Washietl, S.; Kheradpour, P.; Ernst, J.; Jordan, G.; Mauceli, E.; et al. A high-resolution map of human evolutionary constraint using 29 mammals. Nature 2011, 478, 476-482. [CrossRef]

2. $\quad$ Maurano, M.T.; Humbert, R.; Rynes, E.; Thurman, R.E.; Haugen, E.; Wang, H.; Reynolds, A.P.; Sandstrom, R.; $\mathrm{Qu}, \mathrm{H} . ;$ Brody, J.; et al. Systematic localization of common disease-associated variation in regulatory DNA. Science 2012, 337, 1190-1195. [CrossRef] [PubMed]

3. Ward, L.D.; Kellis, M. Interpreting noncoding genetic variation in complex traits and human disease. Nat. Biotechnol. 2012, 30, 1095-1106. [CrossRef] [PubMed]

4. Manocha, S.; Farokhnia, N.; Khosropanah, S.; Bertol, J.W.; Santiago, J.J.; Fakhouri, W.D. Systematic review of hormonal and genetic factors involved in the nonsyndromic disorders of the lower jaw. Dev. Dyn. 2019, 248, 162-172. [CrossRef] [PubMed]

5. Williams, M.A.; Biguetti, C.; Romero-Bustillos, M.; Maheshwari, K.; Dinckan, N.; Cavalla, F.; Liu, X.; Silva, R.; Akyalcin, S.; Uyguner, Z.O.; et al. Colorectal Cancer-Associated Genes Are Associated with Tooth Agenesis and May Have a Role in Tooth Development. Sci. Rep. 2018, 8, 2979. [CrossRef] [PubMed]

6. Fakhouri, W.D.; Rahimov, F.; Attanasio, C.; Kouwenhoven, E.N.; Ferreira De Lima, R.L.; Felix, T.M.; Nitschke, L.; Huver, D.; Barrons, J.; Kousa, Y.A.; et al. An etiologic regulatory mutation in IRF6 with lossand gain-of-function effects. Hum. Mol. Genet. 2014, 23, 2711-2720. [CrossRef] [PubMed]

7. Leslie, E.J.; Taub, M.A.; Liu, H.; Steinberg, K.M.; Koboldt, D.C.; Zhang, Q.; Carlson, J.C.; Hetmanski, J.B.; Wang, H.; Larson, D.E.; et al. Identification of functional variants for cleft lip with or without cleft palate in or near PAX7, FGFR2, and NOG by targeted sequencing of GWAS loci. Am. J. Hum. Genet. 2015, 96, 397-411. [CrossRef] [PubMed]

8. Westra, H.J.; Peters, M.J.; Esko, T.; Yaghootkar, H.; Schurmann, C.; Kettunen, J.; Christiansen, M.W.; Fairfax, B.P.; Schramm, K.; Powell, J.E.; et al. Systematic identification of trans eQTLs as putative drivers of known disease associations. Nat. Genet. 2013, 45, 1238-1243. [CrossRef]

9. Kin, K.; Chen, X.; Gonzalez-Garay, M.; Fakhouri, W.D. The effect of non-coding DNA variations on P53 and cMYC competitive inhibition at cis-overlapping motifs. Hum. Mol. Genet. 2016, 25, 1517-1527. [CrossRef] [PubMed]

10. Onuchic, V.; Lurie, E.; Carrero, I.; Pawliczek, P.; Patel, R.Y.; Rozowsky, J.; Galeev, T.; Huang, Z.; Altshuler, R.C.; Zhang, Z.; et al. Allele-specific epigenome maps reveal sequence-dependent stochastic switching at regulatory loci. Science 2018, 361, 3146. [CrossRef] [PubMed]

11. Cavalla, F.; Biguetti, C.C.; Melchiades, J.L.; Tabanez, A.P.; Azevedo, M.C.S.; Trombone, A.P.F.; Faveri, M.; Feres, M.; Garlet, G.P. Genetic Association with Subgingival Bacterial Colonization in Chronic Periodontitis. Genes 2018, 9, 271. [CrossRef] [PubMed]

12. D'Elia, G.; Caliendo, G.; Casamassimi, A.; Cioffi, M.; Molinari, A.M.; Vietri, M.T. APC and MUTYH Analysis in FAP Patients: A Novel Mutation in APC Gene and Genotype-Phenotype Correlation. Genes 2018, 9, 322. [CrossRef] [PubMed] 
13. Huo, Y.; Zhang, H.Y. Genetic Mechanisms of Asthma and the Implications for Drug Repositioning. Genes 2018, 9, 237. [CrossRef] [PubMed]

14. Iwaszko, M.; Swierkot, J.; Kolossa, K.; Jeka, S.; Wiland, P.; Bogunia-Kubik, K. Influence of NKG2D Genetic Variants on Response to Anti-TNF Agents in Patients with Rheumatoid Arthritis. Genes 2018, 9, 64. [CrossRef] [PubMed]

15. Lacina, P.; Butrym, A.; Mazur, G.; Bogunia-Kubik, K. BSG and MCT1 Genetic Variants Influence Survival in Multiple Myeloma Patients. Genes 2018, 9, 226. [CrossRef] [PubMed]

16. Santiago Junior, J.F.; Biguetti, C.C.; Matsumoto, M.A.; Abu Halawa Kudo, G.; Parra da Silva, R.B.; Pinto Saraiva, P.; Fakhouri, W.D. Can Genetic Factors Compromise the Success of Dental Implants? A Systematic Review and Meta-Analysis. Genes 2018, 9, 444. [CrossRef] [PubMed]

17. Williams, M.A.; Letra, A. The Changing Landscape in the Genetic Etiology of Human Tooth Agenesis. Genes 2018, 9, 255. [CrossRef] [PubMed]

18. Rolandelli, A.; Pellegrini, J.M.; Amiano, N.O.; Santilli, M.C.; Morelli, M.P.; Castello, F.A.; Tateosian, N.L.; Levi, A.; Casco, N.; Palmero, D.J.; et al. The IFNG rs1861494 Single Nucleotide Polymorphism Is Associated with Protection against Tuberculosis Disease in Argentina. Genes 2018, 9, 46. [CrossRef] [PubMed]

19. Mark, E.; Corkins Hannah, L.; Bridget, D.; DeLay Esther, J.; Pearl, M.L.; Hong, J.; Alan, J.; Davidson, M.E.; Horb, R.K. Transgenic Xenopus laevis Line for In Vivo Labeling of Nephrons within the Kidney. Genes 2018, 9 , 197.

20. Martinez, J.R.; Dhawan, A.; Farach-Carson, M.C. Modular Proteoglycan Perlecan/HSPG2: Mutations, Phenotypes, and Functions. Genes 2018, 9, 556. [CrossRef] [PubMed]

(C) 2019 by the authors. Licensee MDPI, Basel, Switzerland. This article is an open access article distributed under the terms and conditions of the Creative Commons Attribution (CC BY) license (http://creativecommons.org/licenses/by/4.0/). 